\title{
Modelling of suspension-feeding and growth in the green-lipped mussel Perna canaliculus exposed to natural and experimental variations of seston avail- ability in the Marlborough Sounds, New Zealand
}

\author{
A. J. S. Hawkins ${ }^{1, *}$, M. R. James ${ }^{2}$, R. W. Hickman ${ }^{3}$, S. Hatton ${ }^{2}$, M. Weatherhead ${ }^{2}$ \\ ${ }^{1}$ Plymouth Marine Laboratory, Centre for Coastal and Marine Sciences, Natural Environment Research Council, West Hoe, \\ Plymouth PL1 3DH, United Kingdom \\ ${ }^{2}$ National Institute of Water and Atmospheric Research Ltd, PO Box 8602, Christchurch, New Zealand \\ ${ }^{3}$ National Institute of Water and Atmospheric Research Ltd, PO Box 14-901, Wellington, New Zealand
}

\begin{abstract}
Responses in feeding behaviour to wide variations in the amount and composition of natural seston were studied in the green-lipped (Greenshell ${ }^{\text {MM }}$ ) mussel Perna canaliculus of standard $58 \pm 2 \mathrm{~mm}$ shell length. Nutrient acquisition was primarily regulated by the rate that mussels cleared water of particles $\left(1 \mathrm{~h}^{-1}\right)$, which varied in hyperbolic relation with the abundance of chlorophyll-rich organics, rather than with the remaining organic or inorganic components of available seston. Maximal clearance rates of about $15 \mathrm{I} \mathrm{h}^{-1} \mathrm{~g}^{-1}$ consistently occurred when chlorophyll a was available at only 1 to $2 \mu \mathrm{g} \mathrm{l}^{-1}$ Although clearance rates decreased exponentially, rates of filtration and ingestion ( $\mathrm{mg} \mathrm{h}^{-1}$ ) continued to grow as the total dry particulate mass (TPM) of available seston increased up to about $1000 \mathrm{mg} \mathrm{l}^{-1}$ The proportion of filtered matter rejected as pseudofaeces before ingestion remained at a constant fraction which averaged 0.87 at seston concentrations above about $40 \mathrm{mg} \mathrm{TPM}^{-1}$. Only above about $1000 \mathrm{mg} \mathrm{TPM} \mathrm{I}^{-1}$ did a decline in filtration rate suggest any physical overloading of feeding mechanisms. Within particles filtered on the ctenidia, significant net enrichment of up to $0.23 \pm 0.10$ (mean $\pm 2 \mathrm{SE}$ ) times the organic fraction in available seston stemmed primarily from the preferential retention of particles that were rich in chlorophyll a. The efficiency of such retention varied in quadratic relation with seston composition, being maximal at an optimal concentration of chlorophyll a per unit total organic matter. Within ingested particles, further net enrichment of up to as much as $1.47 \pm 0.26$ times the organic fraction within filtered matter stemmed from the differential pre-ingestive rejection of particles within pseudofaeces. Efficiencies of both these selective mechanisms increased with filtration rates. The combined effect was that the organic content of ingested matter (OCI) was enhanced at faster filtration rates, to as much as 7 times the organic content of available seston (OCS). Associated benefits were amplified by a positive hyperbolic relation that was confirmed between $\mathrm{OCI}$ and the net absorption efficiency from ingested organics. Findings showed that tissue wasting occurred in $P$. canaliculus of $1 \mathrm{~g}$ dry soft tissue feeding upon seston that contained less than $0.86 \pm 0.19 \mu \mathrm{g}$ chlorophyll a ${ }^{\prime}$. Maximal net organic absorption rate indicated potential growth of $6.5 \% \mathrm{~d}^{-1} \mathrm{~g}^{-1}$ dry soft tissue, associated with the peak in clearance rate. A high capacity for filtration and the ability to adjust clearance rate enabled $P$. canaliculus to optimise particle selection and. absorption efficiencies at levels that maintained organic absorption rate independent of the reduction in OCS as TPM increased to at least $1000 \mathrm{mg} \mathrm{l}^{-1}$ Collective findings help to explain why $P$. canaliculus is so well-suited for cultivation, establish that reduced mussel growth within the New Zealand GreenshellTM industry from 1996 to 1998 was due at least in part to food limitation, and suggest a potential for significant expansion of farming away from traditional 'clear water' sites to more turbid areas.
\end{abstract}

KEY WORDS: Perna canaliculus - Greenshell mussel - Suspension-feeding behaviour Seston composition. Particle selection Chlorophyll . Growth

\section{INTRODUCTION}

Filter-feeding behaviour. in bivalve shellfish is highly responsive to changes in both the abundance and com- position of suspended seston (Bayne 1998), which fluctuate widely within nearshore environments (Bayne \& Widdows 1978, Widdows et al. 1979, Héral et al. 1983, Rodhouse et al. 1984, Smaal et al. 1986, Fegley et al. 
1992, Cranford \& Hargrave 1994). In these environ ments, there are growing pressures to predict the carrying capacities for shellfisheries and to define the role of suspension-feeders in nutrient dynamics (Dame et al. 1980, Cloern 1982, Officer et al. 1982, Doering \& Oviatt 1986, Asmus \& Asmus 1991, 1993, Bayne \& Hawkins 1992, Dame 1993, Héral 1993, Herman 1993, Smaal \& Prins 1993, James \& Ross 1996, 1997). To help understand these processes, many early studies measured the responses of shellfish to artificial suspensions of algal monocultures and/or single inorganic materials such as kaolinite (Bayne \& Newell 1983, Hawkins \& Bayne 1992). It is now clear that selective processes and their consequences are central features of associated behaviour, such that ecologically relevant responses are only evident when feeding upon natural particle mixtures that afford the pre-adapted potential for particle selection (Foster-Smith 1975, Doering \& Oviatt 1986, Cranford \& Gordon 1992, Iglesias et al. 1992, 1996, Navarro et al. 1992, 1994, MacDonald \& Ward 1994, Hawkins et al. 1996, 1998b, Soletchnik et al. 1996, Urrutia et al. 1996, Bacon et al. 1998, MacDonald et al. 1998).

Recent work studying feeding responses in the natural environment as part of the collaborative EC project 'TROPHEE' (refer to Special Issues of the Journal of experimental marine Biology and Ecology Volume 219 and Aquatic Ecology Volume 3, both 1998) has established a common set of functional interrelations between measures of seston availability, seston composition and separate component processes of particle fjltration, pre-ingestive selection and post-ingestive absorption in the mussel Mytilus edulis (Hawkins et al. 1996), the oyster Crassostrea gigas (Soletchnik et al. 1996) and the cockle Cerastoderma edule (Urrutia et al. 1996). Resolution of the exact form of these relations when each species was feeding upon the same natural particle suspensions allowed the successful prediction of feeding rates, organic absorption and growth rates on the basis of seston abundance and composition alone (Hawkins et al. 1996, Soletchnik et al. 1996, Urrutia et al. 1996). These relations obviate the need for physiological measurements, and facilitate the modelling of environmental interrelations, including the carrying capacity of nearshore waters for shellfish culture. They also enable standardised comparisons of relative filter-feeding behaviour, resolving subtle yet ecologically significant differences between the responses observed in separate sympatric species (Hawkins et al. 1998a, b).

In this paper, we study how suspension-feeding behaviour in the green-lipped (Greenshell ${ }^{\mathrm{m}}$ ) mussel Perna canaliculus (Gmelin) responds to wide variations in the amount and composition of natural seston. Observed reponses are used to define functional inter- relations between component processes of organic absorption and to model mussel growth. The Greenshell ${ }^{\mathrm{T}}$ mussel industry represents the New Zealand seafood industry's fifth largest export, earning $N Z \$ 87$ million during 1995 (James \& Ross 1997). This industry is still expanding, capitalising on successful techniques for longline culture that were developed locally (Hickman 1991). Current planning applications for additional extensive mussel farming blocks, combined with reduced growth rates of cultivated mussels during 1996 and 1997, have stimulated widespread concern over whether present levels of mussel production may have reached and even exceeded the carrying capacity beyond which shellfish growth rates are affected (James \& Ross 1997). Despite the socioeconomic significance of this industry, very little is known of feeding behaviour in $P$. canaliculus, the only documented results being in response to artificial suspensions of algal monoculture (Waite 1989). Here, we report findings from work that was undertaken using both natural and experimental variations of seston availability and composition in the Marlborough Sounds, where over $80 \%$ of New Zealand's Greenshell'm production occurs. The range of food availability was substantially wider than in any previous study of bivalve shellfish. This range, together with our development of experimental and analytical techniques, has resulted in novel findings that are likely to apply among filter-feeding bivalve shellfish generally. Interrelations that we define between food availability and feeding behaviour in $P$. canaliculus establish a wide optimal range of feeding conditions over which growth was maximal. Findings will be used to further develop models that predict the environmental carrying capacity for GreenshellTM mussel production (cf. James \& Ross 1996. 1997).

\section{METHODS}

Rope-cultured Perna canaliculus (Gmelin) of $58 \pm 2$ mm shell length were collected on 16 April 1998 from a commercial mussel farm near the entrance to Kenepuru Sound, New Zealand. They were immediately cleared of epibiotic growth and placed within a plastic net bag that was suspended below an isolated jetty situated at the southern end of Wilsons Bay, Pelorus Sound $\left(173^{\circ} 54^{\prime} \mathrm{E}, 41^{\circ} 04^{\prime} \mathrm{S}\right)$. Starting $24 \mathrm{~h}$ later, over a total of $8 \mathrm{~d}$, responses to different experimental feeding conditions were studied on that same jetty. For $1 \mathrm{~d}$ only, we also worked on a boat moored nearshore immediately to the east of Te Puraka Point, Beatrix Bay, Pelorus Sound (174 $\left.04^{\circ} \mathrm{E}, 41^{\circ} 03^{\prime} \mathrm{S}\right)$ Experimental feeding conditions included natural differences in the abundance and composition of sus- 
pended seston, as well as conditions in which seston abundance and composition were manipulated through the variable additions of natural silt and/or cultured alga (Table 1). Those additions ranged up to maximal practical concentrations, with resulting conditions that respresented a dense natural bloom of alga as occur within unmixed eutrophic waters, high concentrations of silt as may be resuspended within nearshore environments such as estuaries, and various combinations of the two. Natural silt was collected by scraping the top $5 \mathrm{~mm}$ from nearby mudflats that were exposed during low tide at the head of Pelorus Sound. Cultured alga was Tetraselmis suecica (Kylin) Butcher raised in $\mathrm{f} / 2$ medium.

For each feeding condition, 10 mussels were individually maintained in separate $200 \mathrm{ml}$ perspex trays that were supplied with natural seawater pumped from alongside the jetty or boat. From day to day, those 10 mussels were randomly drawn from a total of 19 experimental mussels, so that the same 10 mussels were studied under separate feeding conditions on the same day, but different mussels were used on other days and in other conditions. Temperature and conductivity were monitored at regular intervals with an Orion meter. Throughout each feeding condition, the rate of supply and mixture of any added silt or alga were left unchanged. Mussels were first left for up to $1 \mathrm{~h}$ before the rate of seawater flow was adjusted so that concentrations of suspended particles were not reduced by more than an average of $25 \%$ between the inflow and outflow from each shellfish tray. Once finalised at a rate that dif-

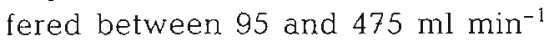
between feeding conditions, the rate of seawater flow through each tray was monitored and adjusted at least hourly to maintain similar values $( \pm 10 \%)$ throughout each condition. Between feeding conditions, maximal flow rates in each shellfish tray ranged between 0.10 and $0.35 \mathrm{~cm} \mathrm{~s}^{-1}$,

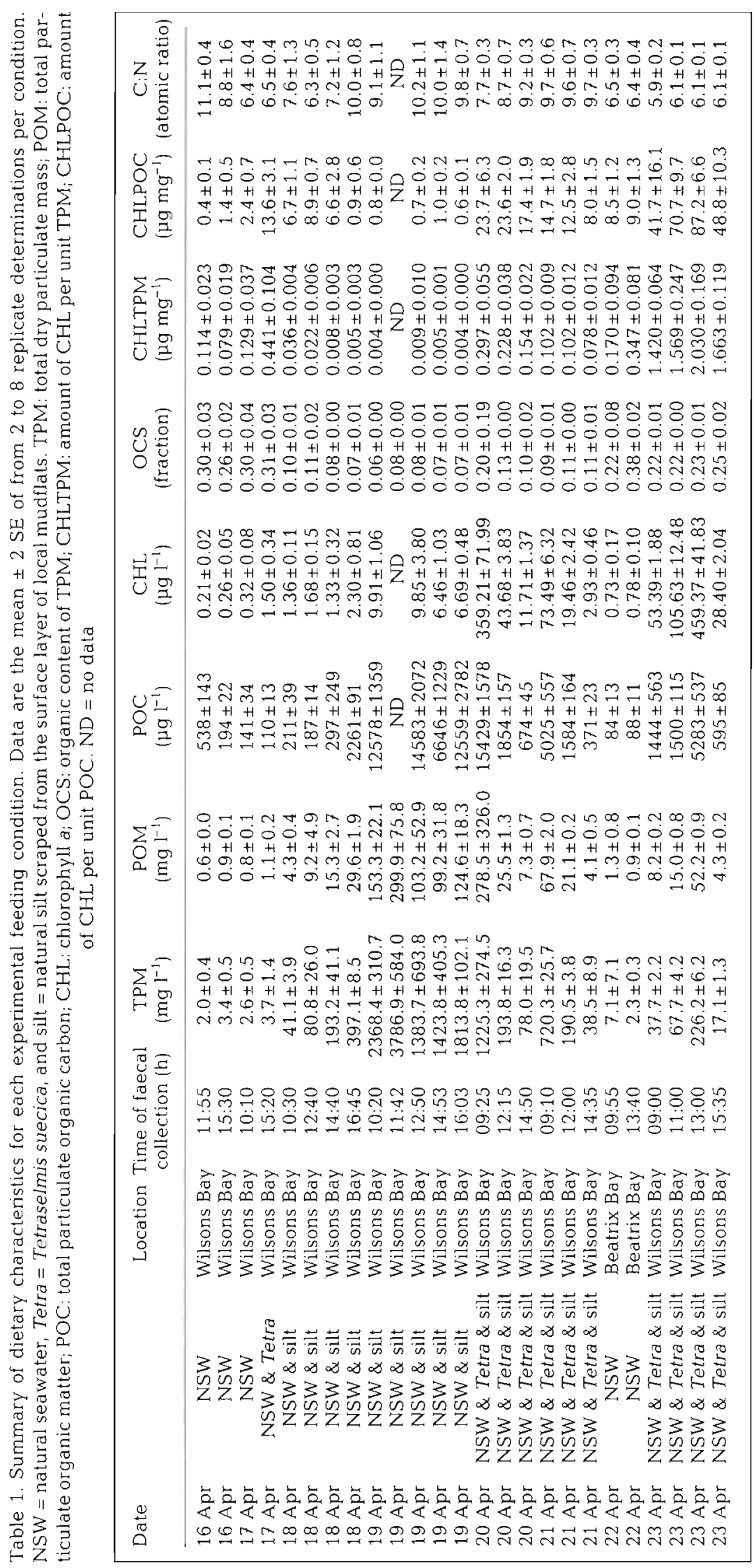


well below rates of $>15 \mathrm{~cm} \mathrm{~s}^{-1}$, which have been shown to inhibit filter-feeding in the mussel Mytilus edulis and other species of bivalve shellfish (e.g Wildish \& Saulnier 1993).

Mussels remained feeding in each condition over intervals that varied between conditions according to when sufficient true faeces had been deposited for subsequent measurements. Times required for the collection of facces ranged between 30 and $215 \mathrm{~min}$. At the end of each feeding condition, the flow rate through each tray was recorded, and up to 31 of seawater were collected from the outflow of each animal tray containing an experimental mussel, as well as from 2 empty control trays. Then, at all but the highest seston concentrations, all true faeces and all pseudofaeces were collected separately from each mussel and homogenised by rapid repeat-pipetting. At the highest seston concentrations, it became impossible to separate true faeces from pseudofaeces, which were therefore sampled together. From water that had been collected from the outflows of each control tray (without mussels), 2 measured aliquots that varied between 25 and $500 \mathrm{ml}$, depending on the seston concentration, were filtered onto separate ashed $25 \mathrm{~mm}$ Whatman GFC filters. One of these filtered aliquots was frozen for the later measurement of chlorophyll a ( $\mathrm{chl} \mathrm{a}$ ) content according to standard procedures for acetone extraction and fluorometric analysis (Holm-Hansen et al. 1965); the other was dried to constant weight at $60^{\circ} \mathrm{C}$ before freezing for later measurement of the particulate carbon and nitrogen contents using a PerkinElmer $2400 \mathrm{CHN}$ elemental analyser. From the outflow water sampled from each control tray and each animal tray, aliquots of $15 \mathrm{ml}$ were analysed for particle concentration using a Coulter Counter Model ZM and tube with $100 \mu \mathrm{m}$ orifice diameter, recording particles larger than $4 \mu \mathrm{m}$ equivalent spherical diameter. Measured aliquots of between 100 and $2500 \mathrm{ml}$ of the seawater collected from the outflows of each control tray and animal tray, as well as measured aliquots from each homogenised faecal sample, were each filtered onto separate pre-weighed and ashed $47 \mathrm{~mm}$ Whatman GFC filters. These were rinsed with approximately $15 \mathrm{ml}$ distilled water to remove salts, and dried at $60^{\circ} \mathrm{C}$ before re-weighing and calculation of the total sample dry weight per filter. Each filter was then ashed at $450^{\circ} \mathrm{C}$ for $4 \mathrm{~h}$ prior to final weighing, allowing calculation both of the ash (inorganic) and ash-free (organic) mass of each filtered sample.

Gut transit times were monitored by transferring 10 mussels which had previously been maintained within natural seawater to a feeding condition that was supplemented with the alga Tetraselmis suecica to a maximal total concentration of $<10$ dry $\mathrm{mg} \mathrm{l}^{-1}$. Algae were seen to be rejected in pseudofaeces within less than
2 min of the start of filtration. The first appearance of true faeces that were enriched with green pigments indicated that ingested alga passed through the digestive tract of mussels with an average $( \pm 2 \mathrm{SE})$ gut transit time of only $80 \pm 9 \mathrm{~min}$. We therefore calculated seston abundance and quality as the integrated average over each corresponding period of faecal collection, having established that samples from the outflows of each empty control tray were representative of the inflow to animal trays. Seston abundance was computed as total dry particulate mass (TPM, $\mathrm{mg} \mathrm{l}^{-1}$ ), total particulate organic matter ( $\mathrm{POM}, \mathrm{mg} \mathrm{l}^{-1}$ ), total particulate organic carbon (POC, $\mu \mathrm{g} \mathrm{l}^{-1}$ ) and chl a (CHL, $\mu \mathrm{g} \mathrm{l}^{-1}$ ). Seston quality was calculated as the organic content of the total dry particulate mass (OCS, fraction), the amount of chl a per unit of the total dry particulate mass (CHLTPM, $\mu \mathrm{g} \mathrm{mg}^{-1}$ ), the amount of chl a per unit of organic carbon (CHLPOC, $\mu \mathrm{g} \mathrm{mg}^{-1}$ ) and the ratio of particulate organic carbon to organic nitrogen $(\mathrm{C}: \mathrm{N}$ ratio).

Processes of feeding and absorption are defined and calculated (Table 2) using some modification of the basic procedures developed by Hawkins et al. (1996), Soletchnik et al. (1996) and Urrutia et al. (1996) as summarized by Hawkins et al. (1998a). Most importantly, this included measurements of the organic and chl a contents of filtered matter (OCF and CHLCF, respectively) (Table 2) using the difference method of Hawkins et al. (1998b). These measurements show how the retention efficiencies for filtered organic matter (REO) and filtered chl a (RECHL) each varied in strong relations with both the abundance and composition of available seston (refer to 'Results'). Therefore, our findings establish the need for accurate individual measures of OCF and CHLCF, which are fundamentally important for dependent calculations of both the rates and efficiencies of filtration, ingestion and absorption (Table 2). In this study, such accuracy could be achieved only after significant seston depletion in each animal tray. With lower net particle depletion, whether due to slower clearance rate $\left(\mathrm{CR}, \mathrm{l} \mathrm{h}^{-1}\right.$ ) with which mussels removed particles larger than $4 \mu \mathrm{m}$ equivalent spherical diameter from seawater, faster throughflow of seawater and/or the pre-ingestive expulsion of filtered algae as a suspension, the calculated. ratio of filtered POM to filtered TPM (= OCF) was increasingly vulnerable to measurement error. To help ensure precision, OCF, REO and associated components of feeding behaviour were calculated only for mussels that depleted $>5 \%$ of the TPM and either POM or CHL between the inflow and outflow of their tray. Similarly, CR was calculated only for mussels that depleted more than $5 \%$ of particles. These collective requirements were not always met, especially when feeding rates were slow at especially low or high ses- 
ton concentrations (refer to 'Results'). Therefore, the number of replicates varied from 2 to 10 mussels between different feeding conditions. In particular, data collected at TPM values of more than about $1000 \mathrm{mg} \mathrm{l}^{-1}$ could not be used to calculate associated responses corrected for selective retention. To obtain a fully comparative measure of feeding rate throughout the complete range of experimental seston concentrations, including experimental conditions when $\mathrm{CR}$ and $\mathrm{OCF}$ were not measured satisfactorily, we calculated the total rate of filtration not corrected for selective retention on the gills (FROCS, $\mathrm{mg} \mathrm{h}^{-1}$ ) (Table 2). This mea- sure of FROCS is similar to all previous gravimetric measures of filtration rate $\left(\mathrm{mg} \mathrm{h}^{-1}\right)$ in bivalve shellfish, except for Hawkins et al. (1998b), who were the first to correct for selective retention.

After the experiment, all soft tissues were excised from each shellfish and dried at $60^{\circ} \mathrm{C}$ before measuring the total soft tissue dry weight, which averaged ( $\pm 2 \mathrm{SE}$ ) $3.68 \pm 0.35 \mathrm{~g}$. To standardise findings and enable comparison with the results from other studies, feeding responses were corrected to those for an equivalent individual of $1 \mathrm{~g}$ dry soft tissue weight using $Y_{\mathrm{s}}=$ $\left(W_{\mathrm{s}} / W_{\mathrm{e}}\right)^{b} \times Y_{\mathrm{e}}$, where $Y_{\mathrm{s}}$ is the standardised parameter,

Table 2. Definitions and descriptions of the calculation of separate components of feeding behaviour

\begin{tabular}{|c|c|c|c|}
\hline Parameter & Acronym & Units & Calculation \\
\hline Clearance rate $^{\mathrm{d}}$ & $\mathrm{CR}$ & $1 \mathrm{~h}^{-1}$ & $\begin{array}{l}\text { (number of particles } \mathrm{ml}^{-1} \text { within the inflow }- \text { number of } \\
\text { particles } \mathrm{ml}^{-1} \text { within the outflow } \div\left(\text { number of particles } \mathrm{ml}^{-1}\right. \\
\text { within the outflow) } \times \text { litre water flow } \mathrm{h}^{-1} \text { through tray }\end{array}$ \\
\hline $\begin{array}{l}\text { Total filtration rate not } \\
\text { corrected for selective retention }\end{array}$ & FROCS & Total mg h $\mathrm{h}^{-1}$ & $\begin{array}{l}\text { (mg inorganic matter egested both as true faeces and } \\
\left.\text { pseudofaeces } \mathrm{h}^{-1}\right) \div(1 \text { - OCS })\end{array}$ \\
\hline $\begin{array}{l}\text { Total filtration rate corrected } \\
\text { for selective retention }\end{array}$ & FROCF & Total $\mathrm{mg} \mathrm{h}^{-1}$ & $\begin{array}{l}\text { (mg inorganic matter egested both as true faeces and } \\
\left.\text { pseudofaeces } \mathrm{h}^{-1}\right) \div(1-\mathrm{OCF})\end{array}$ \\
\hline Filtration rate for organic matter & FRORG & $\mathrm{mg} \mathrm{h}^{-1}$ & $\mathrm{FROCF} \times \mathrm{OCF}$ \\
\hline Filtration rate for chl a alone & FRCHL & $\mu g h^{-1}$ & $\begin{array}{l}\text { (mg inorganic matter egested both as true faeces and } \\
\left.\text { pseudofaeces } \mathrm{h}^{-1}\right) \div\left(\mu \mathrm{g} \text { chl a } \mathrm{mg}^{-1} \text { filtered particulate }\right. \\
\text { inorganic matter })\end{array}$ \\
\hline $\begin{array}{l}\text { Organic content of all } \\
\text { filtered matter }\end{array}$ & $\mathrm{OCF}$ & Fraction & $\begin{array}{l}\text { (mg particulate organic matter } l^{-1} \text { within tray inflow }-\mathrm{mg} \\
\text { particulate organic matter }{ }^{-1} \text { within tray outflow) } \div \text { (mg total } \\
\text { particulate matter } l^{-1} \text { within tray inflow }- \text { mg total particulate } \\
\text { matter } l^{-1} \text { within tray outflow) }\end{array}$ \\
\hline $\begin{array}{l}\text { Chl a content of all } \\
\text { filtered matter }\end{array}$ & CHLCF & $\mu \mathrm{g} \mathrm{mg}^{-1}$ & $\begin{array}{l}\text { ( } \mu \text { g chl a } \mathrm{l}^{-1} \text { within tray inflow }-\mu \mathrm{g} \mathrm{chl} \mathrm{a}^{-1} \text { within tray } \\
\text { outflow) } \div \text { (mg total particulate matter } \mathrm{l}^{-1} \text { within tray inflow - } \\
\text { mg total particulate matter } \mathrm{l}^{-1} \text { within tray outflow) }\end{array}$ \\
\hline $\begin{array}{l}\text { Retention efficiency for all } \\
\text { filtered organic matter }\end{array}$ & $\mathrm{REO}$ & Fraction & $\begin{array}{l}\text { (OCF - organic fraction within total particulates available in } \\
\text { tray inflow) } \div \text { organic fraction within total particulates available } \\
\text { in tray inflow }\end{array}$ \\
\hline $\begin{array}{l}\text { Retention efficiency for filtered } \\
\text { chl a }\end{array}$ & RECHL & Fraction & $\begin{array}{l}\text { (CHLCF }-\mu \mathrm{g} \text { chl } a \mathrm{mg}^{-1} \text { total particulates within tray inflow) }+ \\
\mu \mathrm{g} \mathrm{chl} a \mathrm{mg}^{-1} \text { total particulates available in tray inflow }\end{array}$ \\
\hline Total rejection rate & RRTOT & Total $\mathrm{mg} \mathrm{h}^{-1}$ & mg total pseudofaeces egested $\mathrm{h}^{-1}$ \\
\hline Total ingestion rate & IRTOT & Total $\mathrm{mg} \mathrm{h}^{-1}$ & FROCF - RRTOT \\
\hline $\begin{array}{l}\text { Organic content of all } \\
\text { ingested matter }\end{array}$ & $\mathrm{OCI}$ & Fraction & NOIR $\div($ FROCF - RRTOT $)$ \\
\hline $\begin{array}{l}\text { Net overall organic selection } \\
\text { efficiency }\end{array}$ & NOOSE & Fraction & $(\mathrm{OCl}-\mathrm{OCS}) \div \mathrm{OCS}$ \\
\hline $\begin{array}{l}\text { Net post-filtration organic } \\
\text { selection efficiency }\end{array}$ & NPFOSE & Fraction & $(\mathrm{OCI}-\mathrm{OCF}) \div \mathrm{OCF}$ \\
\hline Net organic ingestion rate & NOIR & $\mathrm{mg} \mathrm{h}^{-1}$ & $\begin{array}{l}(\text { FROCF } \times \text { OCF })-(\text { RRTOT } \times \text { organic fraction within } \\
\text { pseudofaeces })\end{array}$ \\
\hline Net organic absorption rate & NOAR & $m g h^{-i}$ & $\begin{array}{l}\text { NOIR - (mg total true faeces egested } h^{-1} \times \text { organic fraction } \\
\text { within true faeces) }\end{array}$ \\
\hline $\begin{array}{l}\text { Net absorption efficiency from } \\
\text { ingested organics }\end{array}$ & NAEIO & Fraction & NOAR $\div$ NOIR \\
\hline
\end{tabular}


$W_{\mathrm{s}}$ is the standard weight $(1 \mathrm{~g}), W_{\mathrm{e}}$ is the weight or length of the experimental animal, $Y_{e}$ is the uncorrected parameter, and $b$ is the average size exponent of 0.62 for feeding processes in a variety of suspensionfeeding shellfish (Bayne \& Newell 1983).

Net energy balance (NEB, $\mathrm{J} \mathrm{h}^{-1} \mathrm{~g}^{-1}$ ) was calculated as NEB $=-5.8+[0.83 \times(\mathrm{NOAR} \times$ energy content of absorbed organic matter)] on the basis of a linear relation between total heat losses and rate of energy absorption in the mussel Mytilus edulis (Hawkins \& Bayne 1991), where NOAR is the net organic absorption rate expressed as $\mathrm{mg} \mathrm{h}^{-1} \mathrm{~g}^{-1}$ (Table 2), and the energy content of absorbed organic matter was estimated to be $7.25 \mathrm{~J} \mathrm{mg}^{-1}$ according to Hawkins et al. (1996). On this basis, the rate of absorption required to maintain zero NEB (i.e. the 'maintenance ration') would have been $0.96 \mathrm{mg}$ organic matter $\mathrm{h}^{-1}$ in $M$. edulis of $1 \mathrm{~g}$ dry soft tissue.

All statistical analyses were done using SYSTAT for Windows, Version 7 (SYSTAT Inc., Evanston, IL, USA). Feeding responses were related to separate measures of seston abundance and quality using multiple linear regression. These models were fitted in the forwardstepping mode, entering the most significant 'predictor' at the first step, and adding or deleting variables to establish sequentially significant relations, until no further variables were able 'significantly' to improve the overall fit. To help avoid constructing multicolinear models, variables were only included as predictors if (1) their tolerance, calculated as 1 minus the squared multiple correlation between that predictor and the other predictors included in a model, was $>0.01$, and (2) the probability of their correlation with the residual variances for the dependent variable was less than $2.5 \%$.

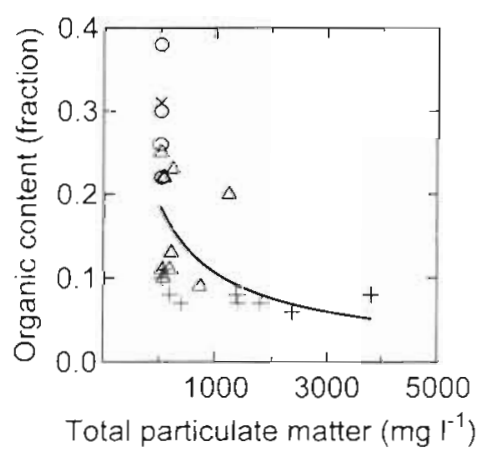

Fig. 1. Relationship between the average organic content (OCS, fraction) and average total particulate mass (TPM, $\mathrm{mg} \mathrm{l}^{-1}$ ) of seston within different experimental feeding conditions. Data are the mean of from 2 to 8 replicate determinations per condition, $(0)$ natural seawater, $(x)$ natural seawater plus cultured Tetraselmis suecica; $(+)$ natural seawater plus natural silt scraped from the surface layer of local mudflats, $(\Delta)$ natural seawater plus cultured $T$ suecica plus natural silt as above

\section{RESULTS}

Seawater temperature and salinity remained constant throughout all measurements, averaging ( $\pm 2 \mathrm{SE}$ ) $16.4 \pm 0.9^{\circ} \mathrm{C}$ and $32.1 \pm 0.04 \%$, respectively. The average $( \pm 2 \mathrm{SE})$ availability and composition of seston measured throughout each feeding condition are summarised in Table 1. Fig. 1 illustrates how, across the full range of seston availability between 2 and $3787 \mathrm{mg} \mathrm{l}^{-1}$. TPM, average seston quality measured as total organic content (OCS) ranged from maximal fractions of 0.3 or above in natural and algal-supplemented seston to minima of 0.07 in silt-supplemented seston, according to a negative relation that was best described by the equation:

$$
\text { OCS }=0.088(0.043,0.178) \times \mathrm{TPM}^{-0.20( \pm 0.06)}
$$

where adjusted $\mathrm{r}^{2}=0.66$, residual $\mathrm{df}=23, \mathrm{p}<0.000001$, and values in parentheses indicate $95 \%$ confidence limits. Over the same range of TPM, average availabilities of chl a increased between different feeding conditions from 0.2 to $459 \mu \mathrm{gl}^{-1}$, whereas average $\mathrm{C}: \mathrm{N}$ ratios ranged from 5.9 to 11.1 (Table 1 ).

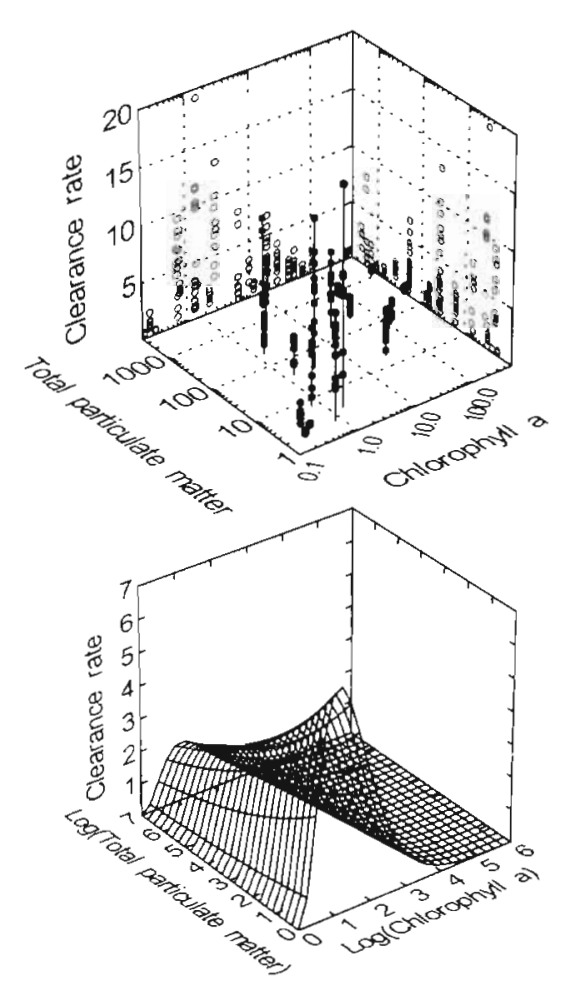

Fig. 2. Perna canaliculus. Clearance rate $\left(C R, I^{-1}\right)$ in relation to seston abundance measured both as chl a $\left(\mathrm{CHL}_{\mathrm{H}} \mathrm{\mu g} \mathrm{l}^{-1}\right)$ and total particulate mass (TPM, $\mathrm{mg} \mathrm{l}^{-1}$ ) in mussels standardised to $1 \mathrm{~g}$ dry soft tissue weight. Findings presented include the original data for individual mussels and a function plot that was fitted by least-squares; refer to Eq. (3) in the 'Results' for parameters and significance level 
Clearance rates $\mathrm{CR}\left(1 \mathrm{~h}^{-1}\right)$ for particles of more than 4 $\mu \mathrm{m}$ equivalent spherical diameter varied with the particulate organic matter within available seston POM $\left(\mathrm{mg} \mathrm{l}^{-1}\right.$ ) according to a relation that was best described by the gamma curve:

$$
\begin{aligned}
\mathrm{CR} & =18.0( \pm 12.2) \times[\log \mathrm{POM} \div 3.26( \pm 3.09)]^{3.33( \pm 1.52)} \\
& \times \exp (-3.33( \pm 1.52) \times\{[\log \mathrm{POM} \div 3.26( \pm 3.09)]-1\})
\end{aligned}
$$

where the mean corrected [1 - (residual sum of squares $\div$ corrected sum of squares) $] \mathrm{r}^{2}=0.13$ and residual $\mathrm{df}=$ 167. However, a much greater total proportion of the total variance in CR (53 vs $13 \%$ ) was associated with both CHL and TPM according to the following combination of gamma curve and exponential equation:

$$
\begin{aligned}
\mathrm{CR} & =6.81( \pm 2.17) \times[\log C H L \div 1.11( \pm 0.42)]^{2.71( \pm 0.42)} \\
& \times \exp (-2.71( \pm 0.42) \times\{[\log C H L \div 1.11( \pm 0.42)]-1\}) \\
& \times[-0.19( \pm 0.08) \log T P M]
\end{aligned}
$$

where mean corrected $\mathrm{r}^{2}=0.53$ and residual $\mathrm{df}=166$. As illustrated in Fig, 2, this indicates that (1) CR initially increased in positive relation with $\mathrm{CHL}$, reaching an estimated maximum $( \pm 2 \mathrm{SE})$ of $6.81( \pm 2.17) \mathrm{l} \mathrm{h}^{-1} \mathrm{~g}^{-1}$ at $1.11( \pm 0.42) \mu \mathrm{g}$ chl a $\mathrm{l}^{-1}$, before declining with further increases in CHL, and (2) the maximum CR decreased in negative exponential relation with TPM.

Filtration rate (estimated as CR $\times$ TPM, $\mathrm{mg} \mathrm{h}^{-1}$ ) varied with filtration measured directly on the basis of
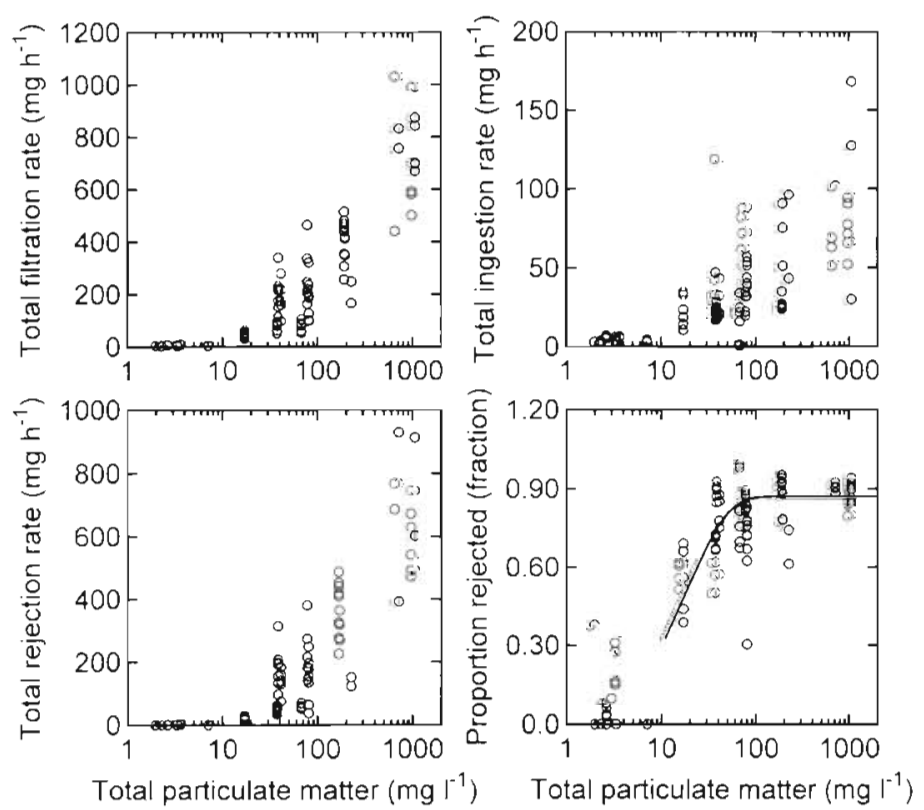

Fig. 3. Perna canaliculus. Rates of total filtration corrected for the selective retention of organic matter (FROCF, $\mathrm{mg} \mathrm{h}^{-1}$ ), total rejection as pseudofaeces (RRTOT, $\mathrm{mg} \mathrm{h}^{-1}$ ), total ingestion rate (IRTOT, $\mathrm{mg} \mathrm{h}^{-1}$ ) and the proportion of filtered matter that was rejected as pseudofaeces (RRTOT $\div$ FROCF; fraction) in relation to the total particulate mass (TPM, mg $\mathrm{I}^{-1}$ ) of available seston in mussels standardised to $1 \mathrm{~g}$ dry soft tissue weight inorganic biodeposition and the organic content of filtered matter (FROCF, $\mathrm{mg} \mathrm{l}^{-1}$ ) (Table 2 ) in a strong positive relation that was best described by the linear equation:

$$
\mathrm{CR} \times \mathrm{TPM}=30.3( \pm 35.5)+0.89( \pm 0.17) \mathrm{FROCF}
$$

where mean corrected $r^{2}=0.53$, residual $d f=90$ and $\mathrm{p}<0.000001$. Fig. 3 illustrates how FROCF, total pseudofaeces rejection rate (RRTOT, $\mathrm{mg} \mathrm{h}^{-1}$ ) and total ingestion rate (IRTOT, $\mathrm{mg} \mathrm{h}^{-1}$ ) increased throughout the full range of TPM, including how the proportion of filtered matter that was rejected as pseudofaeces (RRTOT $\div$ FROCF) remained constant at the highest food availabilities but decreased rapidly as TPM fell below about $40 \mathrm{mg} \mathrm{l}^{-1}$, according to a relation that was best described by the exponential equation:

$$
\begin{aligned}
& \mathrm{RRTOT} \div \mathrm{FROCF}=0.87( \pm 0.40) \\
& \times\left(1-\mathrm{e}^{-0.054( \pm 0.012) \times[T P M}-2.26( \pm 110) \mid\right)
\end{aligned}
$$

where mean corrected $r^{2}=0.88$, residual $\mathrm{df}=111$ and $\mathrm{p}<0.000001$. Multiple stepwise regression analyses established additional influences of seston composition upon FROCF, RRTOT and IRTOT that were each associated with TPM, OCS and/or the chlorophyll content in available TPM (CHLTPM, $\mu \mathrm{g}$ chl a $\mathrm{mg}^{-1}$ TPM) in separate significant relations described by the allometric equations:

$$
\begin{aligned}
\text { FROCF } & =-1.5(0.01,0.12) \times \operatorname{TPM}^{0.48( \pm 0.12)} \\
& \times \mathrm{OCS}^{-2.48( \pm 0.61)} \times \mathrm{CHLTPM}^{0.26( \pm 0.11)}
\end{aligned}
$$

where mean corrected $r^{2}=0.93$, residual $\mathrm{df}=$ 115 and $\mathrm{p}<0.000001$;

$$
\begin{aligned}
\text { RRTOT } & =0.0002(0.0007,0.0009) \times \operatorname{TPM}^{046( \pm 009)} \\
& \times \text { OCS }^{-3.6( \pm 0.51)} \times \text { CHLTPM }^{0.48( \pm 0.09)}
\end{aligned}
$$

where mean corrected $r^{2}=0.93$, residual $\mathrm{df}=$ 144 and $p<0.000001$; and

$$
\begin{aligned}
\text { IRTOT } & =1.11(0.63,1.97) \times \mathrm{TPM}^{0.38( \pm 0.12)} \\
& \times \mathrm{OCS}^{-0.77( \pm 0.49)}
\end{aligned}
$$

where mean corrected $\mathrm{r}^{2}=0.69$, residual $\mathrm{df}=$ 108 and $p<0.000001$.

Fig. 4 illustrates how total filtration rate, not corrected for the selective retention of filtered organic matter (FROCS, mg $\mathrm{h}^{-1}$ ) (Table 2), increased with seston concentration to maximal rates, which occurred at more than $1000 \mathrm{mg}$ $\mathrm{TPM}^{1}{ }^{-1}$, before declining at higher concentrations in a relation that was best described by the polynomial equation:

$$
\begin{aligned}
\text { FROCS } & =-3.14( \pm 76.2)+[1.41( \pm 0.13) \\
& \times \text { TPM }]-\left[7.4 \times 10^{-8}\left( \pm 1.2 \times 10^{-8}\right) \times \mathrm{TPM}^{2}\right]
\end{aligned}
$$

where mean corrected $\mathrm{r}^{2}=0.67$, residual $\mathrm{df}=$ 232 and $\mathrm{p}<0.000001$. 


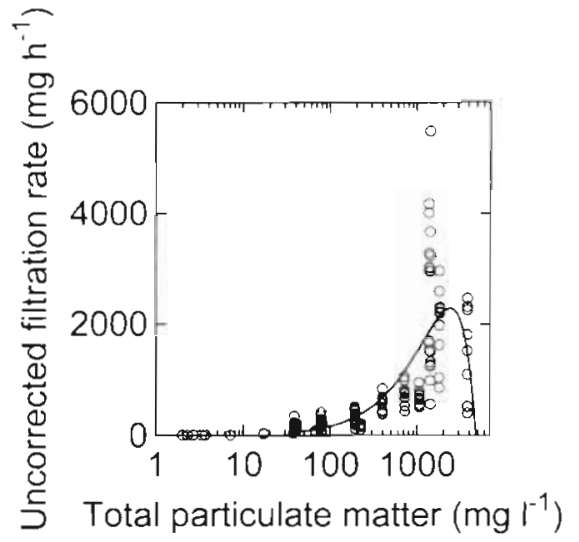

Fig. 4. Perna canaliculus. Rates of total filtration not corrected for the selective retention of organic matter (FROCS, $\mathrm{mg} \mathrm{h}^{-1}$ ) in relation to seston abundance measured as total particulate mass (TPM, $\mathrm{mg} \mathrm{l}^{-1}$ ) in mussels standardised to $1 \mathrm{~g}$ dry soft tissue weight. Data are from individual mussels. The line was fitted by least-squares; refer to Eq. (9) in the 'Results' for parameters and significance level

Over the full range of feeding conditions, a paired samples $t$-test indicated that the average $( \pm 2 \mathrm{SE})$ retention efficiency for filtered organic matter (REO, fraction) $(0.23 \pm 0.10)$ was significantly lower than the average retention efficiency for filtered chlorophyll (RECHL, fraction) $(0.70 \pm 0.36)(t=4.71, \mathrm{df}=56, \mathrm{p}=$ $0.00002)$. Multiple stepwise regression analysis established that $\mathrm{REO}$ varied according to different measures of both seston composition (OCS, fraction; CHLTPM, $\mu \mathrm{g}$ chl $a \mathrm{mg}^{-1}$ TPM; and CHLPOM, $\mu \mathrm{g}$ chl a $\mathrm{mg}^{-1}$ POM) and mussel feeding rate (FROCF, mg total dry seston $\mathrm{h}^{-1}$; and FRORG, mg dry organic matter $\mathrm{h}^{-1}$ ) in a collection of separate significant relations that were best described by the linear equation:

$$
\begin{aligned}
& \text { REO }=0.57( \pm 0.27)+1.46( \pm 0.68) \mathrm{CHLTPM} \\
& -0.31( \pm 0.15) \mathrm{CHLPOM}-2.67( \pm 1.13) \mathrm{OCS} \\
& -0.0015( \pm 0.0004) \mathrm{FROCF}+0.0147( \pm 0.0033) \mathrm{FRORG}
\end{aligned}
$$

where mean corrected $r^{2}=0.56$, residual $d f=101$ and $\mathrm{p}<0.000001$. Compared with REO, more of the variance in RECHL (70 vs $56 \%$ ) was associated with CHLPOM and the rate of chlorophyll filtration (CHLFR, $\mu \mathrm{g} \mathrm{chl} a \mathrm{~h}^{-1}$ ) in separate significant relations that were best described by the combination of quadratic and linear functions:

$$
\begin{aligned}
& \text { RECHL }=-1.26( \pm 0.78)+2.36( \pm 1.29) \text { CHLPOM } \\
& -0.68( \pm 0.32) \text { CHLPOM }{ }^{2}+0.0078( \pm 0.0026) \text { CHLFR }
\end{aligned}
$$

where mean corrected $\mathrm{r}^{2}=0.70$, residual $\mathrm{df}=51$ and $p<0.000001$. Eqs. (10) \& (11) indicate that net organic selection on the ctenidia occurred primarily by the retention of particles that were rich in chlorophyll rather than in non-living plant organics. Further, as is illustrated for RECHL in Fig. 5, there was both an optimal seston composition, measured as chl a per unit total organic matter, at which retention efficiency was maximal, and a positive linear influence of filtration rate. Therefore, organic retention efficiency not only varied according to seston quality, but also with mechanistic processes that were associated with filtration. Net overall organic selection efficiency (NOOSE, fraction), which included the effects both of differential particle retention on the ctenidia and differential particle rejection as pseudofaeces, increased with net post-filtration organic selection efficiency (NPFOSE, fraction) in a positive relation that was best described by the linear equation:

$$
\text { NOOSE }=0.047( \pm 0.35)+1.49( \pm 0.17) \text { NPFOSE }
$$

where adjusted $r^{2}=0.73$, residual $\mathrm{df}=103$ and $\mathrm{p}<$ 0.000001 . Thus, for every increment in NOOSE, an average of $(1 / 1.49) \times 100=67 \%$ of the associated additional organic enrichment resulted from differential rejection of filtered particles within pseudofaeces.
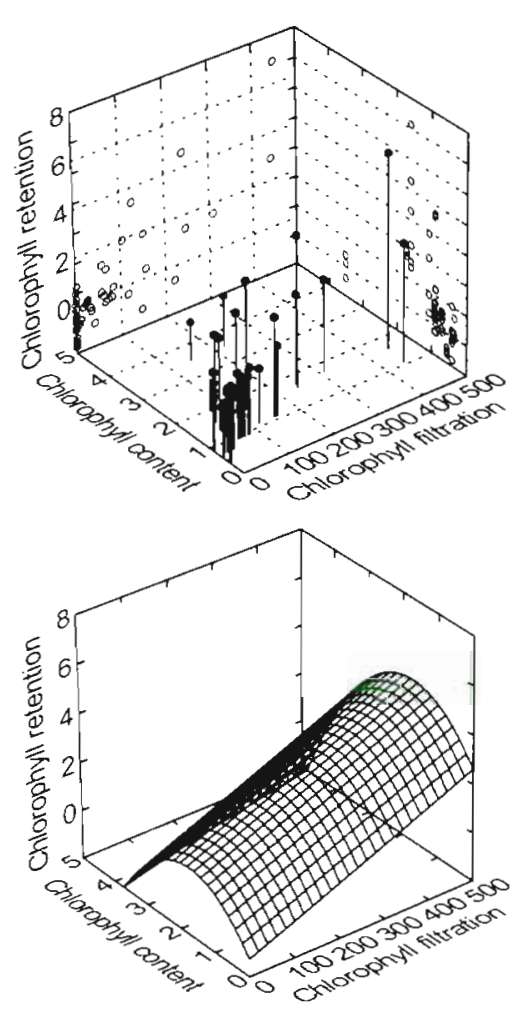

Fig. 5. Perna canaliculus. Retention efficiency for filtered chl a (RECHL, fraction) in relation to seston composition measured both as chl a per unit total organic matter (CHLPOM, $\mu \mathrm{g} \mathrm{mg}^{-1}$ ) and feeding rate measured as rate of chl a filtration (FRCHL, $\mathrm{mg} \mathrm{h}^{-1}$ ) in mussels standardised to $1 \mathrm{~g} \mathrm{dry}$ soft tissue weight. Findings presented include the original data from individual mussels and a function plot that was fitted by least-squares; refer to Eq. (11) in the 'Results' for parameters and significance level 

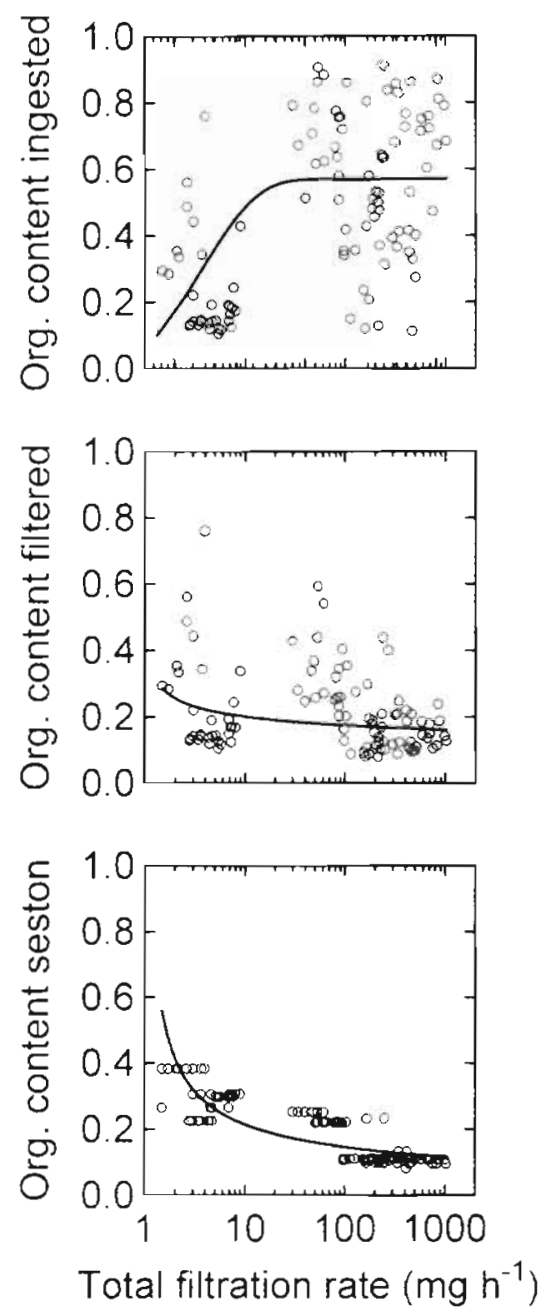

Fig. 6. Perna canaliculus. Organic contents of available seston (OCS, fraction), filtered matter (OCF, fraction) and ingested matter (OCI, fraction) in relation to total filtration rate corrected for the selective retention of organic matter (FROCF, $\mathrm{mg} \mathrm{h}^{-1}$ ) in mussels standardised to $1 \mathrm{~g}$ dry soft tissue weight. Data are from individual mussels. Lines fitted by least squares are described by the equations: OCS $=0.41(0.38,0.45) \times$ FROCF $-0.211 \pm 0.021$, where adjusted $r^{2}=0.78$, residual df $=11$ ? and $\mathrm{p}<0.000001 ; \mathrm{OCF}=0.26(0.21,0.32) \times \mathrm{FROCF}^{-0.08( \pm 0.04)}$, where adjusted $\mathrm{r}^{2}=0.10$, residual $\mathrm{df}=105$ and $\mathrm{p}=0.0006$; and OCI $=0.57( \pm 0.05) \times(1-\exp \{-0.063( \pm 0.088) \times[\mathrm{FROCF}-$ $4.57( \pm 12.64)]\})$, where adjusted $r^{2}=0.36$ and residual $\mathrm{df}=102$

FROCF was the main determinant of NPFOSE, which averaged $1.47 \pm 0.26$ over the full range of feeding conditions, but which varied according to a strong positive relation that was best described by the allometric equation:

NPFOSE $=\left[0.42(0.33,0.54) \times \mathrm{FROCF}^{0.27( \pm 0.02)}\right]-1$

where adjusted $r^{2}=0.84$, residual $\mathrm{df}=103$ and $\mathrm{p}<$ 0.000001 . Multiple stepwise regression did not identify any additional influence of either OCS or OCF on NPFOSE $(p>0.05)$
Fig. 6 illustrates the effects both of differential particle retention on the gills and differential particle rejection as pseudofaeces, including the net result whereby the organic content of ingested matter (OCI, fraction) increased with FROCF up to an average of about 7 times OCS, despite the reduction in OCS at higher TPMs (Fig. 1)

Fig. 7 illustrates how OCI was the primary determinant of net absorption efficiency from ingested organics (NAEIO, fraction) according to a strong positive relation that was best described by the hyperbolic equation:

$$
\text { NAEIO }=1.02( \pm 0.02)-[0.084( \pm 0.007) \times(1 \div \mathrm{OCI})]
$$

where adjusted $r^{2}=0.84$, residual $d f=103$, and $p<$ 0.000001 . It may be seen that NAEIO increased from about 0.2 at the lowest $\mathrm{OCI}$ to average maximal values that were in excess of 0.9 when feeding upon seston with the highest $\mathrm{OCI}$.

Fig. 8 illustrates how net organic absorption rate (NOAR, $\mathrm{mg} \mathrm{h}^{-1}$ ) and net organic ingestion rate (NOIR, $\mathrm{mg} \mathrm{h}^{-1}$ ) each varied with TPM and CHL. Our data do not allow resolution of the correct form of these relations for TPM. However, average $( \pm 2 \mathrm{SE}$ ) rates of NOIR and NOAR when feeding upon chl a concentrations of only 1 to $2 \mu \mathrm{g} \mathrm{l}^{-1}(24.3 \pm 11.4$ and $22.8 \pm 11.3 \mathrm{mg} \mathrm{h}^{-1}$, respectively) were similar to average rates that we recorded when feeding upon all higher chlorophyll concentrations from 2 to $459 \mathrm{\mu g} \mathrm{l}^{-1}$ $(28.2 \pm 7.4, t=0.43, \mathrm{df}=74, \mathrm{p}=0.65 ;$ and $25.9 \pm 7.4$, $t=0.57, \mathrm{df}=74, \mathrm{p}=0.60$, respectively) (Fig. 7). This indicates that rates of nutrient ingestion and absorption were already maximal at these low chlorophyll availabilities, and were maintained throughout all higher seston concentrations. Fig. 9 illustrates how, throughout all feeding conditions when CHL was less than $2.0 \mu \mathrm{g} \mathrm{chl} \mathrm{a} \mathrm{l}^{-1}$. NOAR increased in positive

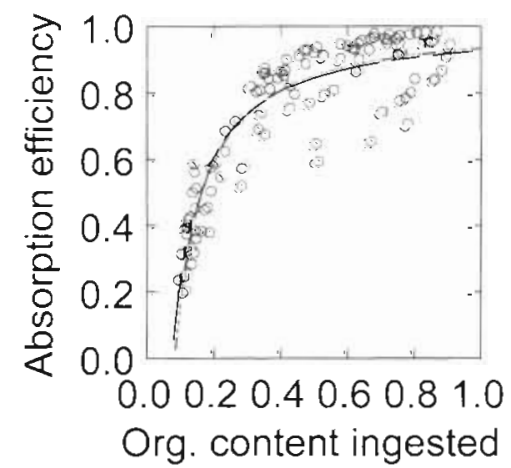

Fig. 7 Perna canaliculus. Net absorption efficiency from ingested organics (NAEIO, fraction) in relation to the organic content of ingested matter (OCI, fraction). Data are from individual mussels. The line was fitted by least-squares; refer to Eq. (14) in the 'Results' for parameters and significance level 


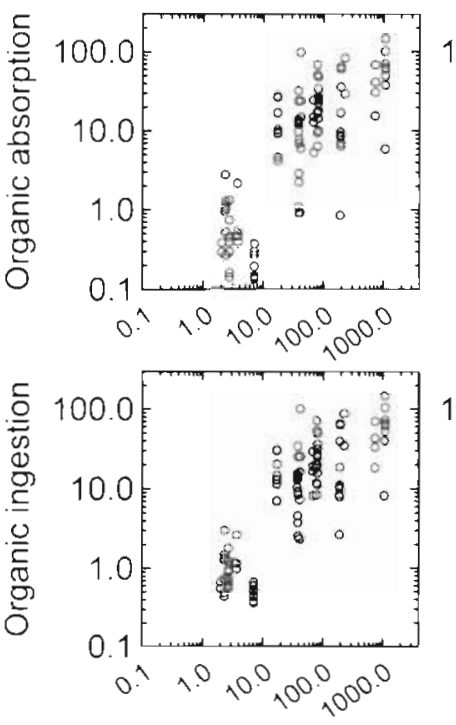

Total particulate matter
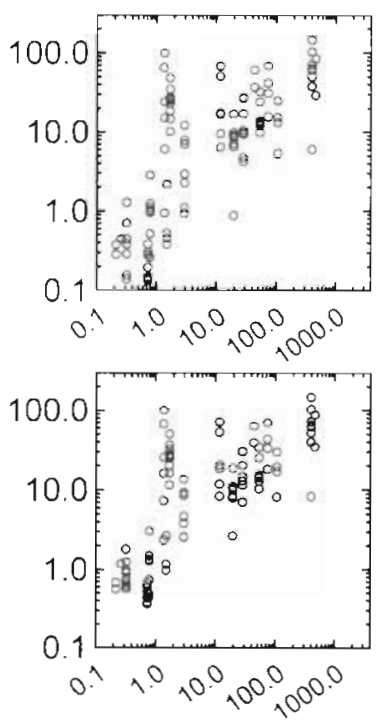

Chlorophyll a
Fig. 8. Perna canaliculus. Net organic absorption rate (NOAR, $\mathrm{mg} \mathrm{h}^{-1}$ ) and net organic ingestion rate (NOIR, $\mathrm{mg} \mathrm{h}^{-1}$ ) in relation to concentrations both of total particulate mass (TPM, mg $\mathrm{l}^{-1}$ ) and the chl a (CHL, $\left.\mu \mathrm{g} \mathrm{I}^{-1}\right)$ in available seston. Data are from individual mussels standardised to $1 \mathrm{~g}$ dry soft tissue weight

exponential relation with CHL according to the following equation:

$$
\text { NOAR }=0.071(0.031,0.162) \times e^{3.03( \pm 0.74) \times \mathrm{CHL}}
$$

where adjusted $\mathrm{r}^{2}=0.58$, residual $\mathrm{df}=46$, and $\mathrm{p}<$ 0.000001 . Given that the mussels need to absorb a maintenance ration of $0.96 \mathrm{mg}$ organic matter $\mathrm{h}^{-1}$ to ensure zero net energy balance ( $N E B, \mathrm{~J} \mathrm{~h}^{-1}$ ) in equivalent mussels of $1 \mathrm{~g}$ dry soft tissue (refer to 'Methods'), this indicates the potential for growth when chl $a$ was available at more than an average of $0.86(0.67,1.02) \mu \mathrm{gg}$ $\mathrm{l}^{-1}$, but that tissue wasting occured when chlorophyll was available at lower concentrations (Fig. 9).

\section{DISCUSSION}

Filter-feeding bivalve shellfish live as benthos within nearshore environments such as estuarine mudflats, where sediments may periodically be resuspended within a high turbidity layer (e.g. Falconer \& Owens 1990, Haure 1996). To better understand how filterfeeders function under such turbid conditions, a growing body of work has studied responses to increasing concentrations of natural seston (Sornin et al. 1983, Deslous-Paoli et al. 1987. Hawkins et al. 1996, Soletchnik et al. 1996, Urrutia et al. 1996, Barillé et al. 1997. Navarro \& Widdows 1997). In the present paper, we

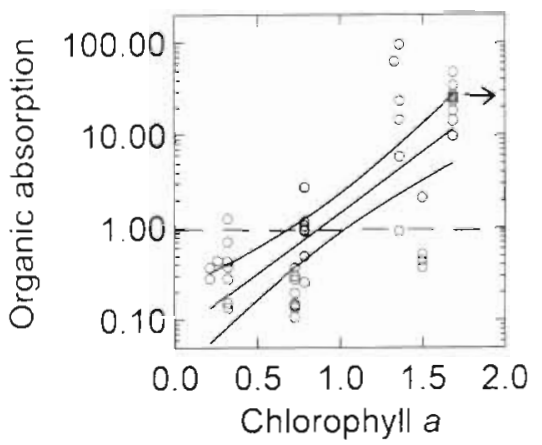

Fig. 9. Perna canaliculus. Net organic absorption rate (NOAR, $\mathrm{mg} \mathrm{h}^{-1}$ ) in relation to concentrations of chl a (CHL, $\mu \mathrm{g} \mathrm{l}^{-1}$ ) in available seston. Data are restricted to $\mathrm{CHL}<2 \mu \mathrm{gl}^{-1}$ and are from individual mussels standardised to $1 \mathrm{~g}$ dry soft tissue weight. Solid line and curves defining $95 \% \mathrm{CL}$ were fitted by least-squares; refer to Eq. (15) in the 'Results' for parameters and significance level. Horizontal dashed line: maintenance ration of $0.96 \mathrm{mg}$ absorbed organic matter $h^{-1}$, required to sustain zero net energy balance (NEB, $\mathrm{J} \mathrm{h}^{-1}$ ) in equivalent mussels of $1 \mathrm{~g}$ dry soft tissue (refer to 'Methods'). Arrow: average NOAR of $25.9 \pm 7.4 \mathrm{mg} \mathrm{l}^{-1}$ for all values of CHL $>2 \mu \mathrm{gl}^{-1}$ (refer to 'Results')

have significantly extended the previous experimental range of up to about $600 \mathrm{mg} \mathrm{TPM} \mathrm{l}^{-1}$ by comparing responses to feeding conditions with average seston concentrations that varied between 2 and as much as $3787 \mathrm{mg}$ TPM I-1 (Table 1). Throughout this range, resuspended sediments resulted in a progressive decrease in the organic content of total available seston (OCS) between average fractions that fell from 0.38 to 0.07 with increasing TPM (Fig 1, Table 2), according to a classic negative relationship that has now been described for natural seston in many different nearshore environments (e.g. Widdows et al. 1979, Navarro et al. 1991, 1993, Hawkins et al. 1996, 1998b). The generality of this relation under both natural and experimental conditions appears to stem primarily from the effects of different water mixing or flow rates that are required to resuspend a common body of natural silt to different concentrations. Within natural suspended silt, particle numbers invariably decline exponentially with increasing size, larger particles settling faster. To maintain higher total concentrations requires greater mixing or flow rates, which help larger particles to remain resuspended. Within natural seston, larger particles generally have lower organic contents (Defossey \& Hawkins 1997). It follows that as TPM increases, the general reduction in OCS reflects increasing proportions of the larger suspended particles.

Our findings show that Perna canaliculus regulated rates of organic absorption and growth independent of ranges of seston availability and composition wider than have hitherto been observed in any bivalve. To achieve such regulation, total filtration rate (FROCS) 
increased with seston concentration to maximal rates at more than $1000 \mathrm{mg} \mathrm{TPM} \mathrm{m}^{-1}$, before declining at higher concentrations (Fig. 4). Presumably, this decline in filtration rate reflected the ultimate overloading of filter-feeding mechanisms. Yet, in previous studies that worked at high seston concentrations, filtration declined above concentrations of about only $100 \mathrm{mg}$ TPM $\mathrm{l}^{-1}$ in the oyster Crassostrea gigas (Sornin et al. 1983, Deslous-Paoli et al. 1987, Barillé et al. 1997) and $300 \mathrm{mg}$ TPM $\mathrm{l}^{-1}$ in the cockle Cerastoderma edule (Navarro \& Widdows 1997). Therefore, compared with these 2 species, the capacity for filtration was considerably greater in $P$. canaliculus.

More subtle, but just as important, we have identified separate selective processes that collectively acted to amplify the organic content of ingested matter (OCI) over and above the organic content of available seston (OCS). These selective processes included (1) differential particle retention on the ctenidia, measured as the retention efficiency for filtered organic matter (REO), and (2) differential pre-ingestive rejection of filtered matter as pseudofaeces, measured as net post-filtration organic selection efficiency (NPFOSE) (Table 2). We establish here that the relative efficiencies of both these selective processes increased in association with filtration rate (refer to Eqs. 10 \& 13 in the 'Results'). The combined result was that OCI more than doubled as FROCF increased throughout its measured range, despite the reduced OCS at higher values of TPM when FROCF was greatest (Fig. 6).

It is clear from Fig. 7 that OCI was the primary determinant of the net efficiency with which nutrients were absorbed from ingested matter (NAEIO, fraction). Without organic enrichment of ingested matter relative to the available seston, NAEIO and associated rates of organic absorption would have decreased rapidly towards zero as OCS fell below 0.1 at higher seston concentrations (Figs. $1 \& 7$ ). Instead, pre-ingestive particle selection helped to ensure that NOAR remained essentially constant between average chl a concentrations that ranged from as little as $1 \mathrm{\mu g}^{\mathrm{I}^{-1}}$ to our experimental maximum of $459 \mu \mathrm{g} \mathrm{I}^{-1}$ (refer to Fig. 8 and 'Results'). A similar dependence of absorption efficiency upon the organic content of ingested particles has been observed in many other species of bivalve shellfish (e.g. Bricelj \& Malouf 1984, Bayne \& Hawkins 1990, Iglesias et al. 1992, Navarro et al. 1993, Barillé et al. 1997, Navarro \& Widdows 1997, Hawkins et al. $1998 \mathrm{a}, \mathrm{b}$ ), suggesting that efficiencies of absorption are primarily limited by digestive processes.

We consistently observed significant net enrichment in the organic content of filtered particles relative to available particles (REO), averaging ( $\pm 2 \mathrm{SE}$ ) $0.21 \pm$ 0.10 over the full range of feeding conditions. This complements similar recent observations in the mussel
Perna viridis and oysters Crassostrea belcheri and Saccostrea cucculata, when significant organic enrichment was associated with declining retention efficiencies for particles within size classes larger than 6 to $12 \mu \mathrm{m}$ equivalent spherical diameter (Hawkins et al. 1998b). Newell et al. (1989) described how the mussel Mytilus edulis preferentially filtered algal cells relative to inorganic particles of equivalent size from natural seston. Further, it is known that $M$. edulis (Newell et al. 1989, Bougrier et al. 1997), the oysters Ostrea edulis (Shumway et al. 1985) and Crassostrea virginica (Bougrier et al. 1997) and the scallops Placopecten magellanicus, Patinopecten yessoensis and Argopecten irradians (Shumway et al. 1997) all preferentially retain different algal species on the ctenidia. In the present work, we have established that net organic enrichment was primarily effected by the retention of particles that were rich in chlorophyll, rather than non-living plant organics (Eqs. $10 \& 11$ ). We have also shown that there was an optimal seston composition at which retention efficiency was maximal, indicating saturation of the selective mechanism for particles that were rich in chl a (Fig 5). This makes clear the potential for error if calculating either total or organic filtration rates as the products of water clearance rate and food availability, as in many past studies on feeding behaviour in bivalve shellfish

Previous studies have established differential preingestive rejection of filtered matter as pseudofaeces on the basis of particle size (Defossey \& Hawkins 1997) and/or particle quality (e.g. Loosanoff 1949, Kiørboe et al. 1980, Newell \& Jordan 1983, Shumway et al. 1985 , Newell et al. 1989, Prins et al. 1991, Cranford \& Gordon 1992, MacDonald \& Ward 1994, Pastoureaud et al. 1996, Bougrier et al. 1997). Our observation that the efficiency of pre-ingestive selection (NPFOSE) (Eq. 13) was also dependent upon filtration rate confirms recent similar observations in a variety of bivalve shellfish (Hawkins et al. 1998a, b). However, findings documented here are the first to show that efficiencies of selective retention on the ctenidia measured as the retentions efficiencies for all filtered organic matter (REO) and for filtered chl a alone (RECHL) also increased with feeding rate. Associated mechanisms have yet to be established. It seems likely that effects involving mucus production (Beninger et al. 1995) and/or flow patterns (Ward et al. 1998a, b) will prove responsible.

The proportion of filtered matter that was rejected as pseudofaeces before ingestion increased to a constant maximum of about 0.9 at TPM values of less than $100 \mathrm{mg} \mathrm{l}^{-1}$, with the result that total ingestion rate (IRTOT) continued to increase throughout its measured range to the maximum that was observed at TPM values of more than $1000 \mathrm{mg} \mathrm{l}^{-1}$ (Fig 3). Clearly, 
pseudofaeces were not only produced to regulate ingestion, being deposited at all but the very lowest seston concentrations, as a by-product of the requirement for pre-ingestive selection from natural particle mixtures. Within the literature, there are many suggestions that pseudofaeces are only produced as an 'overflow' upon reaching a threshold seston concentration above which ingestion rate is saturated. Those suggestions are misleading, being based upon the studied responses to artificial suspensions of algal monocultures that do not afford the opportunity for particle selection and organic enrichment (e.g. Winter 1978).

Clearance rates in the cockle Cerastoderma edule (Iglesias et al. 1992) and the mussels Mytilus edulis (Hawkins et al. 1997) and Perna viridis (Hawkins et al. 1998b) have been shown to decrease in exponential relation to increasing concentrations of POM $\left(\mathrm{mg} \mathrm{I}^{-1}\right)$. The same occurred here in Perna canaliculus. In addition, we have shown that a much greater proportion of the total variance in $\mathrm{CR}\left(\mathrm{l} \mathrm{h}^{-1}\right)$ (53 vs $13 \%$ ) was associated with the concentrations of both chl $a$ and TPM than with POM alone (Eqs. 2 \& 3). Further, both net organic ingestion rate (NOIR) and net organic absorption rate (NOAR) increased to stable maxima that were maintained at all chlorophyll concentrations above between 1 and $2 \mu \mathrm{g} \mathrm{chl} \mathrm{a} \mathrm{l}^{-1}$ (Fig. 8). We have also shown that $\mathrm{CR}$ initially increased in positive relation with $\mathrm{CHL}$, reaching an estimated maximum $( \pm 2 \mathrm{SE}$ ) at $1.11 \pm 0.42 \mu \mathrm{g}$ chl a $\mathrm{l}^{-1}$ before declining with further increases in $\mathrm{CHL}$, and that maximum $\mathrm{CR}$ decreased in negative exponential relation with TPM (Eq. 3, Fig. 2). This indicates that $\mathrm{CR}$ played an important regulatory role, as evidenced by an immediate decline in $\mathrm{CR}$ at all chlorophyll concentrations above the minimum required for maximal rates of organic absorption. The feedback controlling this $C R$ regulation remains uncertain. Responses seemed most closely related to $\mathrm{CHL}$, and thus with the amount of living algal organic matter within suspended seston, rather than with the remaining refractory organic or inorganic components of that seston. This presumably reflected the greater digestibility of chlorophyll-rich organics. But our data do not establish whether that feedback stems directly from biochemical aspects of nutrient absorption and/or energy provision, or whether the observed behaviour may have been in more direct response to gut fullness (e.g. Holling 1966). Given that total ingestion rate continued to increase over ranges of food availability when organic ingestion rate remained essentially stable (Figs. 3 \& 8), any reponse to gut fullness may have been for chlorophyll-rich organic matter, perhaps in the digestive tubules, associated with an established capacity for differential processing of separate particle types (Hawkins \& Bayne 1992).
Our findings confirm the dependence of $\mathrm{CR}$ on both the composition and availability of suspended seston (Hawkins \& Bayne 1992, Bayne 1998), and help to explain apparent contradiction between previous responses that have been observed during feeding upon seston of different composition. In particular, fast CRs have been reported in bivalve shellfish feeding on low availabilities of artificial diets that were comprised predominantly of cultured unicellular algae at maximal experimental concentrations of about $8 \mathrm{mg}$ TPM

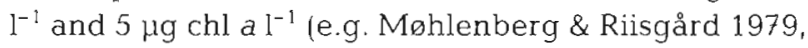
Riisgård 1988, Clausen \& Riisgård 1996, Jørgensen 1996. Hawkins et al. 1997). At higher concentrations of such (artificially) high quality diets, CR decreased with the associated increase in POM (Iglesias et al. 1992, Hawkins et al. 1997, 1998b). Alternatively, positive relations have been observed between $C R$ and the availabilities of natural seston (e.g. Iglesias et al. 1992, Newell \& Shumway 1993, Hawkins et al 1996). That natural seston was mainly comprised of resuspended sediments, with maximal average concentrations of about $80 \mathrm{mg} \mathrm{TPM} \mathrm{l}^{-1}$ but only $3 \mu \mathrm{g} \mathrm{chl} \mathrm{a} \mathrm{l}^{-1}$. Therefore, in the above experiments using natural seston, it seems likely that concentrations of chlorophyll-rich organics were below the optima required for maximal $C R$, NOIR and NOAR, which would explain the positive dependence of $C R$ upon seston availability that we observed over our lowest concentrations of less than about $2 \mu \mathrm{g}$ chl a $\mathrm{l}^{-1}$ (Eq. 3, Fig. 3). These comparisons emphasise the highly flexible regulation of $\mathrm{CR}$ in Perna canaliculus and other filter-feeding bivalve shellfish, responding to changes in seston abundance and composition to maintain FRTOT and associated selective processes within the limits that are required to optimise NOIR, OCI and ultimately NOAR.

NOIR was maintained at maximal values that averaged ( $\pm 2 \mathrm{SE}$ ) $27.3 \pm 6.3 \mathrm{mg} \mathrm{h}^{-1}$ for all concentrations of chl a above $1 \mu^{-g^{-1}}$ (Fig. 8). A similar NOIR of $24.8 \pm 3.6$ $\mathrm{mg}$ organics $\mathrm{h}^{-1}$ was recorded in the green mussel Perna viridis from Malaysia, but this may not have been maximal (Hawkins et al. 1998b). The only other experimental measure of maximal feeding rates in another mussel diagnosed the saturation of digestive processes when ingestion had reached about $6.5 \mathrm{mg}$ organics $\mathrm{h}^{-1}$ in Mytilus edulis of $1 \mathrm{~g}$ dry soft tissue (Hawkins et al. 1997). These differences between the rate of ingestion in Perna species and $M$. edulis are consistent with observations that $P$. canaliculus (Hickman 1979), P. perna (Mandelli \& Acuna 1975) and $P$. viridis (Rajagopal et al. 1998) all reach marketable size (>60 mm shell length) after growing for 6 to $9 \mathrm{mo}$, compared with much longer periods of 11 to more than 24 mo in $M$. edulis (Hickman 1979). Therefore, faster growth in Perna species than in $M$. edulis stems at least in part from increased weight-specific rates of energy 
acquisition. This is consistent with previous conclusions based upon the comparative allometries of different physiological processes, which indicate that limitations to growth in various bivalve species result primarily from their relative capacities to process food, rather than from any underlying metabolic differences (Hawkins et al. 1990).

Net energy balance (NEB) averaged ( \pm 2 SE) 145 $\pm 37 \mathrm{~J} \mathrm{~h}^{-1}$ at all concentrations of chl a above $1 \mu \mathrm{g} \mathrm{l}^{-1}$. Mussel tissue has an energy content of about $23.5 \mathrm{~J}$ $\mathrm{mg}^{-1}$ dry soft tissue (Slobodkin \& Richman 1961), and at least $44 \%$ of all the energy/carbon that is available for production is deposited within soft tissue rather than in byssus or shell (Hawkins \& Bayne 1985). On this basis, the present measure of maximal NEB indicates potential net growth of $(145 \div 23.5) \times 0.44 \times 24=$ $65 \mathrm{mg}$ dry soft tissue $\mathrm{d}^{-1}$ in Perna canaliculus of $1 \mathrm{~g}$ dry soft tissue, which represents $6.5 \%$ of soft tissue $\mathrm{d}^{-1}$. Using the original data of Hickman \& Illingworth (1980), who compared the seasonal performances of $P$. canaliculus at different sites around New Zealand, we have calculated that soft tissue increased at an average of up to $8.6 \% \mathrm{~d}^{-1}$ over monthly periods of maximal growth in mussels of $1 \mathrm{~g}$ dry soft tissue. Therefore, maximal rates of growth that we predict from our experimental observations of feeding behaviour approximate those observed directly in nature.

In conclusion, we have documented feeding responses over a range of seston availability wider than hitherto studied in any bivalve shellfish. We were especially careful to accurately measure the net efficiencies with which organic matter and chl a were filtered from suspension. Our findings build upon previous understanding of filter-feeding behaviour, identifying novel interrelations and further resolving the functional basis of established responses. To summarise, feeding and nutrient acquisition were primarily regulated by clearance rate $\left(1 \mathrm{~h}^{-1}\right)$, which increased and decreased in hyperbolic relation with the abundance of chlorophyllrich organics. Maximal clearance rates occurred between only 1 and $2 \mu \mathrm{g} \mathrm{chl} \mathrm{a} \mathrm{l}^{-1}$, and decreased in negative exponential relation with TPM. Despite reduced clearance rate, both filtration rate $\left(\mathrm{mg} \mathrm{h}^{-1}\right)$ and ingestion rate $\left(\mathrm{mg} \mathrm{h}^{-1}\right)$ continued to increase up to seston availabilities of about $1000 \mathrm{mg} \mathrm{TPM}^{-1}$, for the rate of rejection as pseudofaeces $\left(\mathrm{mg} \mathrm{h}^{-1}\right)$ remained at a constant fraction that averaged 0.87 of filtration rate at ses-

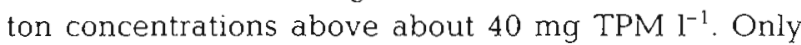
above about $1000 \mathrm{mg} \mathrm{TPM} \mathrm{I}^{-1}$ did a decline in filtration rate suggest any mechanistic overloading of feeding mechanisms. The associated capacity for filtration was higher than previously reported in any filter-feeder. Functional benefits associated with faster filtration were increased efficiencies with which organic matter was selectively retained on the ctenidia and increased efficiencies with which organic matter was selectively rejected as pseudofaeces before ingestion. Together these selective processes enhanced the organic content of ingested matter up to about 7 times the organic content of available seston, helping to maintain organic ingestion rate independent of the reduced organic content of seston available at higher TPMs, with ensuing benefits of a positive relation that was confirmed between the organic content of ingested matter and absorption efficiency from ingested organics. Collective interrelations establish a wide optimal range of feeding conditions over which maximal organic absorption rate and net energy balance were achieved at low seston

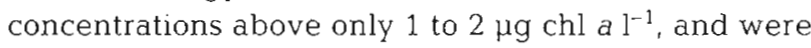
maintained, despite the increasing 'dilution' of organic matter by inorganic silt, as TPM increased up until at least $1000 \mathrm{mg}$ of natural sediment $\mathrm{l}^{-1}$. Chl a has generally been available at concentrations ranging between 1 and $5 \mu \mathrm{g} \mathrm{l}^{-1}$ at sites associated with mussel farming throughout New Zealand (e.g. Gibbs et al. 1992, Gibbs \& Vant 1998). But between 1996 and early 1998, perhaps associated with climatic shifts in ocean circulation and/or reduced rainfall/nutrient runoff, chlorophyll concentrations were below $1 \mu \mathrm{g} \mathrm{l}^{-1}$ throughout the same nearshore waters (Ross et al. 1999), at a time of reduced mussel condition and growth (James \& Ross 1997; refer to 'Introduction'). Findings presented here show that significant mussel growth only occurred when chl a was available at more than $1.02 \mathrm{\mu g} \mathrm{l}^{-1}$ (refer to 'Results'). Therefore, decreased chlorophyll availability at least partially explains the slower growth observed within New Zealand's Greenshell ${ }^{T M}$ industry from 1996 to 1998. Farming of Perna canaliculus has traditionally been undertaken in relatively clear water with low sediment concentrations, thereby enhancing perception of a 'clean' product. We have demonstrated impressive capacities for filtration and differential particle selection that enabled $P$. canaliculus to maintain maximal rates of growth over a wide range of feeding conditions that included much more turbid environments than have previously been investigated. Dependent upon further validation, including tolerance of other environmental variables such as salinity, this appears to offer the potential for significant expansion of mussel farming away from traditional sites, to areas that may offer more stable optimal nutrition, whilst also relieving the pressures of overstocking.

Acknowledgements. This work represents part of (1) Strategic Research Project 3, entitled 'Marine Biodiversity', of the Plymouth Marine Laboratory, a component laboratory of the Centre for Coastal and Marine Sciences of the UK Natural Environment Research Council, and (2) the 'Sustainability of Cultured Shellfisheries' Programme, funded by the New Zealand Foundation for Research Science and Technology (C01604). A.J.S.H. acknowledges the National Institute of 
Water and Atmospheric Research Ltd, New Zealand, for support provided following an invitation through their Visiting Scientist programme. We thank Dr Bob Clarke for statistical advice, Dr Barbara Hayden for practical help, Mr Bob Greg for donating our experimental mussels, and 2 anonymous referees for constructive comments. We are grateful to Mr John Henderson and Mr Eric Huddleston for assistance whilst acting as skippers of the motor vessels 'Nancy Jean' and 'Miss Raetihi', respectively. We also thank Mr and Mrs John May for reliable support at the Te Rawa Boatel.

\section{LITERATURE CITED}

Asmus RM, Asmus H (1991) Mussels beds: limiting or promoting phytoplankton? J Exp Mar Biol Ecol 148:215-232

Asmus H, Asmus RM (1993) Phytoplankton-mussel bed interactions in intertidal ecosystems. In: Dame RF (ed) Bivalve filter feeders in estuarine and coastal ecosystem processes. Springer-Verlag, Berlin, p 57-84

Bacon GS, MacDonald BA, Ward JE (1998) Physiological responses of infaunal (Mya arenaria) and epifaunal (Placopecten magellanicus) bivalves to variations in the concentration and quality of suspended particles. I. Feeding activity and selection. J Exp Mar Biol Ecol 219:87-103

Barillé L, Héral M, Barillé-Boyer AL (1997) Modélisation de l'écophysiologie de l'huitre Crassostrea gigas dans un environnement estuarien. Aquat Living Resour 10:31-48

Bayne BL (1998) The physiology of suspension feeding by bivalve molluscs: an introduction to the Plymouth 'TROPHEE' workshop. J Exp Mar Biol Ecol 219:1-19

Bayne BL, Hawkins AJS (1990) Filter-feeding in bivalve molluscs: controls on energy balance. In: Mellinger J (ed) Animal. nutrition and transport processes, Vol 1. Nutrition. in wild and domestic animals. Karger, Basel, p $70-83$

Bayne BL, Hawkins AJS (1992) Ecological and physiological aspects of herbivory in benthic suspension-feeding molluscs. In: John DM, Hawkins SJ, Price JH (eds) Plant-animal interaction in the marine benthos. Systematics Association Spec Vol No. 46. Clarendon Press, Oxford, p 265-288

Bayne BL, Newell RC (1983) Physiological energetics of marine molluscs. In: Wilbur KM, Saleuddin AS (eds) The Mollusca, Vol 4. Academic Press, New York, p 407-515

Bayne BL, Widdows J (1978) The physiological ecology of two populations of Mytilus edulis.L. Oecologia 37:137-162

Beninger PG, St-Jean SD, Poussart Y (1995) Labial palps of the blue mussel Mytilus edulis (Bivalvia: Mytilidae). Mar Biol 123:293-303

Bougrier S, Hawkins AJS, Héral M (1997) Preingestive selection of different microalgal mixtures in Crassostrea gigas and Mytilus edulis, analysed by flow cytometry. Aquaculture 150:123-134

Bricelj VM, Malouf RE (1984) Influence of algal and suspended sediment concentrations on the feeding physiology of the hard clam Mercenaria mercenaria. Mar Biol 84: $155-165$

Clausen I, Riisgård H (1996) Growth, filtration and respiration in the mussel Mytilus edulis: no evidence for physiological regulation of the filter pump to nutritional needs. Mar Ecol Prog Ser 141:37-45

Cloern JE (1982) Does benthos control phytoplankton biomass in south San Francisco Bay? Mar Ecol Prog Ser 9: $191-202$

Cranford PJ, Gordon DC Jr (1992) The influence of dilute clay suspensions on sea scallop (Placopecten magellanicus) feeding activity and tissue growth. Neth J Sea Res 30: $107-120$
Cranford PJ, Hargrave BT (1994) In situ time-series measurement of ingestion and absorption rates of suspension-feeding bivalves: Placopecten magellanicus. Limnol Oceanogr 39:730-738

Dame RF (1993) The role of bivalve filter feeder material fluxes in estuarine ecosystems. In: Dame RF (ed) Bivalve filter feeders in estuarine and coastal ecosystem processes. Springer-Verlag, Berlin, p 245-270

Dame RF, Zingmark R, Stevenson $H_{1}$ Nelson D (1980) Filter feeder coupling between the estuarine water column and benthic subsystems. In: Kennedy VS (ed) Estuarine perspectives. Academic Press, New York, p 521-526

Defossey JM, Hawkins AJS (1997) Selective feeding in shellfish: size-dependent rejection of large particles within psuedofaeces from Mytilus edulis, Ruditapes philippinarum and Tapes decussatus. Mar Biol 129:139-148

Deslous-Paoli JM, Sornin JM, Héral M (1987) Variations saisonnières in situ de la production de biodépôts de trois mollusques estuariens, Mytilus edulis, Crassostrea gigas, Crepidula fornicata. Haliotis 16:233-245

Doering $\mathrm{PH}_{1}$ Oviatt CA (1986) Application of filtration rate models to field populations of bivalves: an assessment using experimental mesocosms. Mar Ecol Prog Ser 31: $265-275$

Falconer RA, Owens PH (1990) Numerical modelling of suspended sediment fluxes in estuarine waters. Estuar Coast Shelf Sci 31:745-762

Fegley SR, MacDonald BA, Jacobsen TR (1992) Short-term variation in the quantity and quality of seston available to benthic suspension feeders. Estuar Coast Shelf Sci 34: $393-412$

Foster-Smith RL (1975) The effect of concentration of suspension and inert material on the assimilation of algae by three bivalves. J Mar Biol Assoc UK 55:411-418

Gibbs MM, Vant WN (1998) Seasonal changes in factors controlling phytoplankton growth in Beatrix Bay, New Zealand. NZ J Mar Freshw Res 31:237-248

Gibbs MM, Pickmere SE, Woods PH, Payne GW, James MR, Hickman RW. Illingworth J (1992) Nutrient and chlorophyll a variability at six stations associated with mussel farming in Pelorus Sound, 1984-85. NZ J Mar Freshw Res 26:197-211

Haure J (1996) Effets du vent sur la remise en suspension particulaire en baie de Bourgneuf: conséquences sur la croissance de Crassostrea gigas. J Rech Oceanogr 21:88 (Abstract)

Hawkins AJS, Bayne BL (1985) Seasonal variation in the relative utilization of carbon and nitrogen by the mussel Mytilus edulis: budgets, conversion efficiencies and maintenance requirements. Mar Ecol Prog Ser 25:181-188

Hawkins AJS, Bayne BL (1991) Nutrition of marine mussels: factors influencing the relative utilizations of protein and energy. Aquaculture 94:177-196

Hawkins AJS, Bayne BL (1992) Physiological processes, and the regulation of production. In: Gosling $E$ (ed) The mussel Mytilus: ecology, physiology, genetics and culture. Elsevier Science Publishers BV. Amsterdam, p 171-222

Hawkins AJS, Navarro E, Iglesias JIP (1990) Comparative allometries of gut content, gut passage time and metabolic faecal loss in Mytilus edulis and Cerastoderma edule. Mar Biol 105:197-204

Hawkins AJS, Smith RFM, Bayne BL, Héral M (1996) Novel observations underlying fast growth of suspension-feeding shellfish in turbid environments: Mytilus edulis. Mar Ecol Prog Ser 131:179-190

Hawkins AJS, Smith RFM, Bougrier S, Bayne BL, Héral M (1997) Manipulation of dietary conditions for maximal 
growth in mussels, Mytilus edulis L., from the MarennesOléron Bay, France. Aquat Living Resour 10:13-22

Hawkins AJS, Bayne BL, Bougrier S, Héral M, Iglesias JIP, Navarro E, Smith RFM, Urrutia MB (1998a) Some general relationships in comparing the feeding physiology of suspension-feeding bivalve molluscs. J Exp Mar Biol Ecol 219:87-103

Hawkins AJS, Smith RFM, Tan SH, Yasin ZB (1998b) Suspension-feeding behaviour in tropical bivalve molluscs: Perna viridis, Crassostrea belcheri, Crassostrea iradelei, Saccostrea cucculata and Pinctada margarifera. Mar Ecol Prog Ser 166:73-185

Héral M (1993) Why carrying capacity models are useful tools for management of bivalve molluscs culture. In: Dame RF (ed) Bivalve filter feeders in estuarine and coastal ecosystem processes. Springer-Verlag, Berlin, p 455-478

Héral M, Deslous-Paoli JM, Sornin JM (1983) Transferts énergétics entre l'huître Crassostrea gigas et la nourriture potentielle disponible dans un bassin ostréicole: premières approches. Oceanis 9:169-194

Herman PMJ (1993) A set of models to investigate the role of benthic suspension feeders in estuarine ecosystems. In: Dame RF (ed) Bivalve filter feeders in estuarine and coastal ecosystem processes. Springer-Verlag, Berlin, p 421-454

Hickman RW (1979) Allometry and growth of the greenlipped mussel Perna canaliculus in New Zealand. Mar Biol 51:311-327

Hickman RW (1991) Perna canaliculus (Gmelin) in New Zealand. In: Menzel W (ed) Estuarine and marine bivalve mollusc culture. CRC Press, Boca Baton, p 325-334

Hickman RW, Illingworth $J$ (1980) Condition cycle of the green-lipped mussel Perna canaliculus in New Zealand. Mar Biol 60:27-38

Holling CS (1966) The functional response of invertebrate predators to prey density. Mem Entomol Soc Can 48:1-86

Holm-Hansen O, Lorenzen CJ, Holmes RW, Strickland JDH (1965) Fluorometric determination of chlorophyll. J Cons Int Explor Mer 30:3-15

Iglesias JIP, Navarro E, Alvarez Jorna P, Armentia I (1992) Feeding, particle selection and absorption in cockles Cerastoderma edule (L.) exposed to variable conditions of food concentration and quality. J Exp Mar Biol Ecol 162: $177-198$

Iglesias JIP, Urrutia MB, Navarro E, Alvarez-Jorna P, Larretxea X, Bougrier $S$, Héral $M(1996)$ Variability of feeding processes in the cockle Cerastoderma edule (L.) in response to changes in seston concentration and composition. J Exp Mar Biol Ecol 197:121-143

James MR, Ross AH (1996) How many mussels can we farm? Seafood NZ 4:50-53

James MR, Ross AH (1997) Sustainability - how many mussels can we farm? Aquacult Update 18:1-4

Jørgensen CB (1996) Bivalve filter feeding revisited. Mar Ecol Prog Ser 142:287-302

Kiørboe T, Møhlenberg F, Nohr O (1980) Feeding, particle selection and carbon absorption in Mytilus edulis in different mixtures of algae and resuspended bottom material. Ophelia 19:193-205

Loosanoff VS (1949) On the food selectivity of oysters. Science 110:122

MacDonald BA, Ward JE (1994) Variation in food quality and particle selectivity in the sea scallop Placopecten magellanicus (Mollusca: Bivalvia). Mar Ecol Prog Ser 108: $251-264$

MacDonald BA, Bacon GS, Ward JE (1998) Physiological responses of infaunal (Mya arenaria) and epifaunal (Pla- copecten magellanicus) bivalves to variations in the concentration and quality of suspended particles. II. Absorption efficiency and scope for growth. J Exp Mar Biol Ecol 219:127-141

Mandelli EF, Acuna AC (1975) The culture of the mussel Perna perna and the mangrove oyster Crassostrea rhizophorae in Venezuela. Mar Fish Rev 37:15-18

Møhlenberg F, Riisgård HU (1979) Filtration rate, using a new indirect technique, in thirteen species of suspension-feeding bivalves. Mar Biol 54:143-147

Navarro E, Iglesias JIP, Perez Camacho A, Labarta U, Berias R (1991) The physiological energetics of mussels (Mytilus galloprovincialis Lmk.) from different cultivation rafts in the Ria de Arosa (Galicia, N. W. Spain). Aquaculture 94: $197-212$

Navarro E, Iglesias JIP, Ortega MM (1992) Natural sediment as a food source for the cockle Cerastoderma edule (L.): effect of variable particle concentration on feeding, digestion and the scope for growth. J Exp Mar Biol Ecol 156: $69-87$

Navarro E, Iglesias JIP, Ortega MM, Larretxea X (1994) The basis for a functional response to variable food quantity and quality in cockles Cerastoderma edule (Bivalvia, Cardiidae). Physiol Zool 67:468-496

Navarro JM, Widdows J (1997) Feeding physiology of Cerastoderma edule in response to a wide range of seston concentrations. Mar Ecol Prog Ser 152:175-186

Navarro JM, Clasing E, Urrutia G, Asencio G, Stead R, Herera $C$ (1993) Biochemical composition and nutritive value of suspended particulate matter over a tidal flat of southern Chile. Estuar Coast Shelf Sci 37:59-73

Newell CR, Shumway SE (1993) Grazing of natural particulates by bivalve molluscs: a spatial and temporal perspective. In: Dame RF (ed) Bivalve filter feeders in estuarine and coastal ecosystem processes. Springer-Verlag, Berlin, p 85-148

Newell CR, Shumway SE, Cucci TL, Selvin R (1989) The effects of natural seston particle size and type on feeding rates, feeding selectivity and food resource availability for the mussel Mytilus edulis Linnaeus, 1758 at bottom culture sites in Maine. J Shellfish Res 8:187-196

Newell RIE, Jordan SJ (1983) Preferential ingestion of organic material by the American oyster Crassostrea virginica. Mar Ecol Prog Ser 13:7-53

Officer CB, Smayda TJ, Mann R (1982) Benthic filter feeding: a natural eutrophication control? Mar Ecol Prog Ser 9: 203-210

Pastoureaud A, Héral M, Prou J, Razet D, Russu P (1996) Particle selection in the oyster Crassostrea gigas (Thunberg) studied by pigment HPLC analysis under natural food conditions. Oceanol Acta 19:79-88

Prins TC, Smaal AC, Pouwer AJ (1991) Selective ingestion of phytoplankton by the bivalves Mytilus edulis L. and Cerastoderma edule (L.). Hydrobiol Bull 25:93-100

Rajagopol S, Venugopalan VP, Nair KVK, van der Velde G, Jenner HA, den Hartog $C$ (1998) Reproduction, growth rate and culture potential of the green mussel, Perna viridis (L.) in Edaiyur backwaters, east coast of India. A.quaculture 162:187-202

Riisgård HU (1988) Efficiency of particle retention and filtration rate in 6 species of northeast American bivalves. Mar Ecol Prog Ser 45:217-223

Rodhouse PG, Roden CM. Brunnell GM, Hensey MP, McMahon T, Ottway B, Ryan TH (1984) Food resource, gametogenesis and growth of Mytilus edulis on the shore and in suspended culture: Killary Harbour, Ireland. J Mar Biol Assoc UK 64:513-529 
Ross A, Gibbs M, James M, Osbourne T. (1999) Changes in nutrients affecting phytoplankton abundance in Pelorus Sound 1994-1998. Seafood NZ (in press)

Shumway SE, Cucci TL, Newell RC, Yentch TM (1985) Particle selection, ingestion and absorption in filter-feeding bivalyes. J Exp Mar Biol Ecol 91:77-92

Shumway SE, Cucci TL, Lesser MP, Bourne $N$, Bunting B (1997) Particle clearance and selection in three species of juvenile scallops. Aquacult Int 5:89-99

Slobodkin LB, Richman S (1961) Calories/gm in species of animals. Nature 191:299

Smaal AC, Prins TC (1993) The uptake of organic matter and the release of inorganic nutrients by bivalve suspension feeder beds. In: Dame RF (ed) Bivalve filter feeders in estuarine and coastal ecosystem processes. Springer-Verlag, Berlin, p 271-298

Smaal AC, Verhagen JHG, Coosen J, Haas HA (1986) Interaction between seston quantity and quality and benthic suspension feeders in the Oosterschelde, The Netherlands. Ophelia 26:385-399

Soletchnik P, Goulletquer P, Héral M, Razet D, Geairon P (1996) Évaluation du bilan énergétique de l'huitre creuse, Crassostrea gigas, en baie de Marennes-Oleron (France). Aquat Living Resour 9:65-73

Sornin JM, Feuillet M, Héral M, Deslous-Paoli JM (1983) Effet de biodépôts de l'huître Crassostrea gigas (Thunberg) sur

Editorial responsibility: Otto Kinne (Editor),

Oldendorf/Luhe, Germany l'accumulation de matières organiques dans le bassin de Marennes-Oléron. J Mollusc Stud 12:185-197

Urrutia MB, Iglesias JIP, Navarro E, Prou J (1996) Feeding and absorption in Cerastoderma edule under environmental conditions in the bay of Marennes-Oléron (Western France). J Mar Biol Assoc UK 76:431-450

Waite RP (1989) The nutritional biology of Perna canaliculus with special reference to intensive mariculture systems. PhD thesis, Department of Zoology, University of Canterbury, NZ

Ward JE, Levinton JS, Shumway SE, Cucci T (1998a) Particle sorting in bivalves: in vivo determination of the pallial organs of selection. Mar Biol 131:283-292

Ward JE, Sanford LP, Newell RIE, MacDonald BA (1998b) A new explanation of particle capture in suspension-feeding bivalve molluscs. Limnol Oceanogr 43:741-752

Widdows J, Fieth P, Worrall CM (1979) Relationships between seston, available food and feeding activity in the common mussel Mytilus edulis. Mar Biol 50:195-207

Wildish DJ, Saulnier AM (1993) Hydrodynamic control of filtration in Placopecten magellanicus. J Exp Mar Biol Ecol $174: 65-82$

Winter JE (1978) A review of the knowledge of suspensionfeeding in lamelibranchiate bivalves, with special reference to artificial aquaculture systems. Aquaculture 13: $1-33$

Submitted: February 5, 1999; Accepted: July 13, 1999 Proofs received from author(s): December 14, 1999 